J. Lake Sci. (湖泊科学) , 2019, 31(5): 1279-1288

DOI 10. 18307/2019. 0524

(c) 2019 by Journal of Lake Sciences

\title{
太湖流域湖荡湿地生态系统健康评价"
}

\author{
徐红玲 ${ }^{1,2}$, 潘继征 ${ }^{1 * *}$, 徐力刚 ${ }^{3}$, 路学军 ${ }^{4}$, 赵 敏 $^{1,2}$, 杨鸿山 ${ }^{1,5}$, 吴晓东 ${ }^{6}$ \\ (1: 中国科学院南京地理与湖泊研究所, 湖泊与环境国家重点实验室, 南京 210008) \\ (2: 中国科学院大学, 北京 100049) \\ (3: 中国科学院南京地理与湖泊研究所, 中国科学院流域地理学重点实验室, 南京 210008) \\ ( 4 : 连云港市环境监测中心站,连云港, 222001) \\ (5: 苏州科技大学环境科学与工程学院,苏州 215009) \\ (6:湖北师范大学城市与环境学院,黄石 435002)
}

\begin{abstract}
摘 要: 太湖流域湖荡湿地影响着整个流域生态系统的健康运转, 是湖泊水体与陆地之间的过渡带, 对周边城市的生态 环境起到重要的净化调节作用, 对太湖流域湖荡湿地生态系统健康进行评价, 有利于湖荡湿地的科学管理, 从而实现湖 荡湿地资源的可持续利用. 本文选择太湖流域 11 个典型的湖荡湿地为研究对象, 于 2012-2015 年开展周年湿地观测季 度调查. 利用主客观组合赋权方法, 结合太湖流域自然条件和社会功能, 提出了基于生态可修复性指标的太湖流域湖荡 湿地生态系统健康评价体系和方法. 结果表明: 太湖流域湖荡湿地中生态系统健康等级为优的占 $27.27 \%$, 分别是傀儡湖、 尚湖和钱资荡; 生态系统健康等级为良的湖荡湿地占 $9.09 \%$, 为长荡湖; 中等生态系统健康水平的湖荡湿地居多, 占 $36.36 \%$, 分别是阳澄湖、昆承湖、元荡和淀山湖; 生态系统健康等级为差的湖荡湿地占 $18.18 \%$, 分别是滆湖、澄湖和宜兴三 氿. 本研究建立的湖泊生态健康评估体系和湖泊生态健康评价结果对太湖流域湖荡湿地的后续有效管理具有重要的现 实意义.
\end{abstract}

关键词: 太湖流域;湖荡湿地;生态系统健康评价; 综合健康指数

\section{Ecological system health evaluation of lacustrine wetland in Taihu Basin}

XU Hongling ${ }^{1,2}$, PAN Jizheng ${ }^{1 * *}$, XU Ligang ${ }^{3}$, LU Xuejun ${ }^{4}$, ZHAO Min ${ }^{1,2}$, YANG Hongshan ${ }^{1,5} \&$ WU Xiaodong $^{6}$

(1: State Key Laboratory of Lake Science and Environment, Nanjing Institute of Geography and Limnology, Chinese Academy of Sciences, Nanjing 210008, P.R.China)

(2: University of Chinese Academy of Sciences, Beijing 100049, P.R.China)

(3: Key Laboratory of Watershed Geographic Sciences, Nanjing Institute of Geography and Limnology, Chinese Academy of Sciences, Nanjing 210008, P.R.China)

(4: Lianyungang Environmental Monitoring Station, Lianyungang 222001, P.R. China)

(5: School of Environmental and Engineering, Suzhou University of Science and Technology, Suzhou 215009, P.R.China)

(6: College of Urban and Environmental Sciences, Hubei Normal University, Huangshi 435002, P.R.China)

Abstract: Taihu Basin, the transitional zone between the land and the lake, influents the health of the whole river basin ecosystem, and plays an important regulatory role in the purification of the surrounding city ecological environment. The health assessment of wetland ecosystem in Taihu Basin is advantageous to the scientific management of lake wetland, so as realizing the sustainable $\mathrm{u}$ tilization of float lake wetland resources. In this paper, water quality were investigated based on 11 typical lake wetlands of Taihu Basin during the period of 2012-2015, and try to build a method of the health assessment of wetland ecosystem in Taihu Basin,

* 国家水体污染控制与治理科技重大专项(2017ZX07204-5) 和江苏高校水处理技术与材料协同创新中心项目联合 资助. 2018-11-19 收稿;2019-03-12 收修改稿. 徐红玲 (1994 ), 女, 硕士研究生; E-mail: striving_ling@ foxmail. com.

** 通信作者;E-mail: jzhpan@ niglas.ac.cn. 
which considered the method of subjective and the objective weight-deciding, combined the natural condition with social function of Taihu Basin and propose ecological repairable index creatively. The results showed that Lake Kuilei, Lake Shang and Lake Qianzi are the lake wetlands with excellent healthy ecosystem in the Taihu Basin. The healthy level of Lake Changdang ecosystem is good. There are some lake wetlands with the middle healthy level in the Taihu Basin, such as Lake Yangcheng, Lake Kuncheng, Lake Yuandang and Lake Dianshan. Lake Ge, Lake Cheng and Lake Sangui are in the poor healthy level. The lake ecological health assessment system and lake ecological health assessment results established in this paper are of great practical significance for the management of lacustrine wetlands in Taihu Basin.

Keywords: Taihu Basin; lake wetlands; ecosystem health assessment; comprehensive health index

湖荡湿地生态系统是湿地植物、栖息于湿地的动物、微生物及其环境组成的统一整体, 是集自然、经济、 社会于一体的复合系统,具有储蓄水源、防洪补枯、提供生物栖息地环境、降解和转化污染物、调节区域气候 等多种多样的功能 ${ }^{[1-5]}$. 太湖是我国长江中下游地区第三大淡水湖泊. 随着太湖流域城市化规模的不断扩 大,湿地生态系统遭受到前所未有的威胁与破坏. 如何监测和评估湿地生态系统健康状况, 修复和保护受损 湿地生态系统, 已成为当今湿地管理的重要内容 ${ }^{[6-10]}$. 因此, 开展太湖流域湖荡湿地生态系统健康评价, 对于 正确地评估太湖流域湖荡湿地生态系统结构功能及历史演变趋势, 分析湖荡湿地水质、水生生物状况及其 变化过程与规律,弄清湖荡湿地生态健康状况和可修复性具有重要的理论指导意义.

湖泊生态系统健康评价常用方法包括生态系统健康指数法、模糊综合评价方法、综合健康指数法等. Xu 应用该方法对巢湖生态系统健康进行评价, 并阐明了该方法的可行性 ${ }^{[11]}$. 为了更好地评估生态系统健康, 学者们将生态模型引人到生态系统健康评价研究中, 特别是模糊综合评价的方法应用效果较好. PSR (Pressure-State-Response) 模型是比较常用的评价模型, 麦少芝等对该模型的概念、内容、作用及其应用进行了详 细说明, 但该综合评价是基于模糊数学原理, 无法将定量的评价因子进行模糊定量转换 ${ }^{[12]}$, 因此有学者提出 综合健康指数法. 综合健康指数法通过给评价指标分配不同的权重, 以计算生态系统的健康指数, 权重的确 定方法有专家打分法、经验赋值等. 而刘江等采用卡尔森综合营养状态指数法 $(T L I(\Sigma))$, 以叶绿素 a 的状 态指数 $T L I(\mathrm{Chl} . \mathrm{a})$ 为基准, 获得评价水体的综合营养状态指数 ${ }^{[13]}$; 侯思琰等也是采用综合健康指数评价方 法从 5 个指标对河流进行优良中等级评价并提出对应的修复措施 ${ }^{[14]}$, 但该方法无法完全套用于湖荡湿地生 态系统健康评价. 综合以上论述, 构建一种基于物理、化学和生物的生态完整性评价方法可以作为水生态系 统健康 (生态完整性) 评价的优先方法.

胡志新等采用生态系统健康指数法对太湖不同区域的生态系统健康状况进行了评价, 认为太湖不同湖 区的生态系统健康状况存在一定的差异性 ${ }^{[15]}$; 蔡琨等利用太湖浮游植物生物完整性指数评价冬季太湖水生 态健康质量 ${ }^{[16]}$; 许妍等运用 PSR 模型选取胁迫因子、状态因子以及效应因子构建生态系统健康指标体系评 价了太湖流域综合生态健康 ${ }^{[17]}$; 陈桥等以底栖动物为指标, 评价太湖流域平原水网水生态健康 ${ }^{[18]}$; 戈锋等 采用熵权综合指数法构建太湖水生态系统健康评价指标体系, 评价太湖湖滨带不同分区生态系统的健康 状态 ${ }^{[19]}$.

从已有研究看, 围绕太湖展开的生态健康评价研究较多, 而对于太湖流域湖荡湿地生态健康评价研究 仍处于探索阶段. 因此, 基于太湖流域湖荡湿地众多且水体受到不同程度污染这一现状 ${ }^{[20]}$, 本文通过建立 太湖流域湖荡湿地生态系统健康评估体系, 得出太湖流域湖荡湿地的健康评价结果, 探讨太湖流域湖荡湿 地生态系统健康水平及太湖流域湖荡湿地受损水体的水生态修复潜力, 以期为太湖流域湖荡湿地生态修复 目标的确定提供理论指导.

\section{1 材料和方法}

\section{1 研究区域概况}

选取太湖流域典型的 11 个湖荡湿地, 分别为滆湖、长荡湖、尚湖、昆承湖、阳澄湖、傀儡湖、澄湖、淀山 湖、元荡、钱资荡和宜兴三氿, 于 2012-2015 年开展湿地季度调查, 采样点位分布见图 1, 湖荡面积和平均水 深见表 1 . 


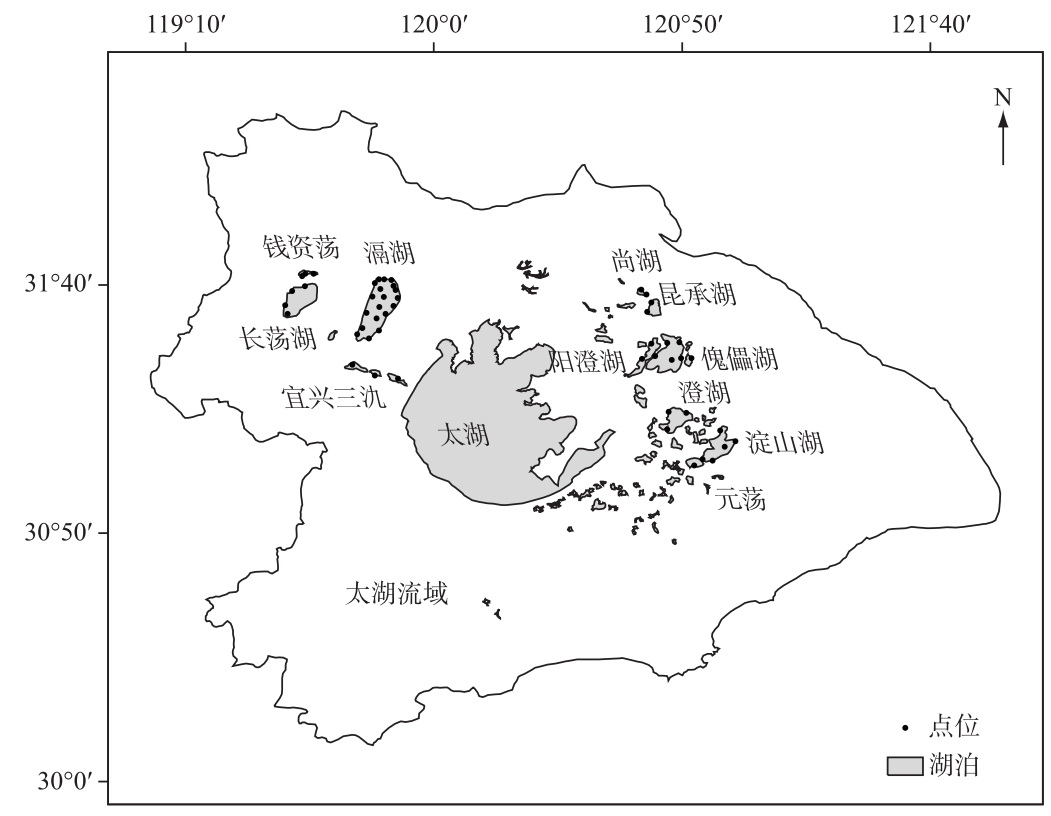

图 1 太湖流域湖荡湿地采样点分布

Fig.1 Location of sampling sites in Taihu Basin

\section{2 数据采集与分析}

2012-2015 年期间,按季度 (1、4、7、10 月) 对太湖流域 11 个湖荡湿地进行逐年采样调查, 采样点数量如表 2 所示.

使用有机玻璃采水器采集表层水样,混合均匀后倒人 $250 \mathrm{ml}$ 玻璃采样瓶. 利用 $\mathrm{AP}-2000$ 多参数水质分析仪及便携 式溶氧仪 (HQ40D, 哈希) 测定水温、pH 和溶解氧( DO) 浓度进 行现场测定. 样品置于低温保温箱内保存并运回实验室, 迅速 分析水体的总氮 $(\mathrm{TN})$ 、总磷 (TP) 浓度和高锰酸盐指数 $\left(\mathrm{COD}_{\mathrm{Mn}}\right)$, 水样过 $0.45 \mu \mathrm{m}$ 醋酸纤维膜的上覆水用于测定溶 解性总氮 (DTN)、溶解性有机氮 $(\mathrm{DON})$ 、铵态氮 $\left(\mathrm{NH}_{4}^{+}-\mathrm{N}\right)$ 、硝 态氮 $\left(\mathrm{NO}_{3}^{-}-\mathrm{N}\right)$ 、亚硝态氮 $\left(\mathrm{NO}_{2}^{-}-\mathrm{N}\right)$ 和正磷酸盐 $\left(\mathrm{PO}_{4}^{3-}-\mathrm{P}\right)$ 浓度, 分析方法均参照《水和废水监测分析方法》 $(\text { 第四版 })^{[22]}$. 水 质标准参照《地表水环境质量标准》( GB 3838-2002). 对采 集的水样进行抽滤 $(0.22 \mu \mathrm{m})$, 滤液中的有机物即为有色可溶 性有机物 (CDOM). 紫外一可见光全波扫描 (UV-Vis) : 将经
表 1 太湖流域湖荡面积和平均水深

Tab.1 The area and average depth of lakes in Taihu Basin

\begin{tabular}{ccc}
\hline 湖泊名称 & 面积 $/ \mathrm{km}^{2}$ & 平均水深 $/ \mathrm{m}$ \\
\hline 滆湖 & 164 & 1.20 \\
阳澄湖 & 119.04 & 1.82 \\
长荡湖 & 89 & 1.10 \\
澄湖 & 45 & 1.83 \\
尚湖 & 8 & 1.9 \\
钱资荡 & 6.9 & 1.0 \\
昆承湖 & 18 & 1.78 \\
宜兴三氿 & 13.5 & 1.4 \\
元荡 & 12.9 & 2.6 \\
淀山湖 & 62 & 2.1 \\
傀儡湖 & 6.73 & 2.1 \\
\hline
\end{tabular}

$\mathrm{GF} / \mathrm{F}$ 膜 $\left(450^{\circ} \mathrm{C}\right.$ 灼烧 $4 \mathrm{~h}$ ) 过滤的水样用紫外可见分光光度计 (UV2700, 岛津) 扫描测定可溶性有机物 (DOM) 吸 收光谱, 扫描范围为 $200 \sim 800 \mathrm{~nm}$, 间隔为 $1 \mathrm{~nm}$. 水生生物指标主要包括高等植物的覆盖度、浮游植物种类和密 度、浮游动物种类和密度等, 现场采样保存方法参照《湖泊富营养化调查规范》(第二版) $)^{[21]}$.

\section{3 水生态系统健康评估方法}

1.3.1 水生态系统健康评估指标 在天然湖泊中, 沉水植物的分布及其变化, 最主要的控制因子是水下光照 条件, 因此本文选取受损水体修复潜力这一指标建立太湖流域湖荡湿地综合评估指标体系 (表 3). 秦伯强 等在分析湖泊生态恢复的关键因子中提出水域真光层深度与水深的比值可以反映水生态系统是否是草型 生态系统 ${ }^{[22]}$. 大部分太湖流域湖荡湿地经过底质改良后, 透明度与水深比值成为沉水植被恢复的限制因子. 受损水体修复潜力 (透明度/ 水深) 作为本文首次提出的评价指标, 其评价结果对各湖荡沉水植被修复潜力 
有良好的指示意义.

受损水体修复潜力 $\left(\mathrm{C}_{3}\right)$ : 主要考虑太湖流域湖荡湿地水环境质量的特点, 选择透明度/平均水深来作为 湖荡湿地沉水植被修复的直观表征形式.

表 2 太湖流域湖荡采样点数量*

Tab.2 The number of sampling sites in Taihu Basin

\begin{tabular}{|c|c|c|c|c|c|c|c|c|c|c|c|}
\hline 湖泊名称 & 滆湖 & 阳澄湖 & 长荡湖 & 澄湖 & 尚湖 & 钱资荡 & 昆承湖 & 宜兴三氿 & 元荡 & 淀山湖 & 傀儡湖 \\
\hline 采样点数 & 20 & 6 & 8 & 3 & 2 & 2 & 2 & 3 & 2 & 4 & 2 \\
\hline
\end{tabular}

* 根据实际湖盆的形态、湖泊的面积以及湖泊的自然条件等因素, 滆湖和长荡湖分别选择了其中 8 和 6 个点位进行指标 评价.

表 3 太湖流域湖荡湿地综合评估指标体系

Tab.3 Comprehensive evaluation index system of lake wetlands in Taihu Basin

\begin{tabular}{lllll}
\hline 目标层 $(\mathrm{H})$ & 类别层 $(\mathrm{A})$ & 要素层 $(\mathrm{B})$ & 必选指标 $(\mathrm{C})$ & 可选指标 \\
\hline 太湖流域湖荡 & 湖荡湿地自然生态 & 物理 $\left(\mathrm{B}_{1}\right)$ & 口门畅通率 $\left(\mathrm{C}_{1}\right)$ & 湖滨带完整度 \\
湿地综合指数 $(\mathrm{H})$ & 健康系统 $\left(\mathrm{A}_{1}\right)$ & & 湖水交换能力 $\left(\mathrm{C}_{2}\right)$ & 湖水交换能力 \\
& & & 受损水体修复潜力 $\left(\mathrm{C}_{3}\right)$ & $\begin{array}{l}\text { 湖泊底部沉积物营养物含量 } \\
\end{array}$ \\
& 化学 $\left(\mathrm{B}_{2}\right)$ & 综合水质指标 $\left(\mathrm{C}_{4}\right)$ & 水质类别、水质类别面积比 \\
& & 富营养指数 $\left(\mathrm{C}_{5}\right)$ & 综合营养状态指数 $T L I$ \\
& 生物 $\left(\mathrm{B}_{3}\right)$ & 蓝藻密度 $\left(\mathrm{C}_{6}\right)$ & 蓝藻数量比例 \\
& & 生物多样性 $\left(\mathrm{C}_{7}\right)$ & 水生植物、浮游植物、浮游动物 \\
& & & 和底栖动物的多样性 \\
& & & 防洪工程完好率 \\
& & & 湖荡湿地社会服务 \\
& 功能系㧤 $\left(\mathrm{A}_{2}\right)$ & & 水功务能区水质达标率 $\left(\mathrm{B}_{4}\right)$ & 水源地取水口位置 \\
& & 公众环境满意度 $\left(\mathrm{C}_{10}\right)$ & 水生态环境保护投入 \\
& & &
\end{tabular}

针对太湖流域湖荡湿地, 本研究将湖荡湿地自然生态健康评估分为物理、化学和生物 3 个要素, 指标层 次体系分为目标层、类别层、要素层以及指标层 4 个层次, 评价目标层为太湖流域湖荡湿地综合指数, 其下 层包括湖泊自然生态健康以及社会服务功能健康 2 个类别, 其评价指标层由口门畅通率等 7 个必选指标及 湖泊开发利用率等 6 个待选指标: 湖荡湿地社会服务功能健康评估包括社会服务要素, 对应调蓄防洪能力、 功能区水质达标率和公众环境满意度 3 个必选指标以及防洪工程完好率等 3 个选用指标.

1.3.2 水生态系统健康评价方法 湖荡湿地水生态系统健康综合评价的目的在于服务于湖泊治理和管理决 策, 指标权重的确定需要结合评价者对该指标的价值判断, 即对指标本身重要性程度的认知; 此外, 由于评 价指标体系中多数为定量指标, 指标特征值多客观地反映待评湖泊的真实特征, 评价过程中又须考虑指标 特征值的真实特征. 因此为获得切合实际的评价结果, 必须采用主、客观相结合的组合赋权方法.

本研究采用层次分析法 (Analytic Hierarchy Processing, AHP) 主观赋予指标特征权重值. 层次分析法体 现了“分解一判断一综合” 的基本决策思维过程,把问题的各个因素分解, 按照支配关系分组形成有序的递 阶层次结构,两两比较来确定层次中各因素的相对重要性, 并利用判断矩阵特征向量的计算确定下层指标 对上层指标的贡献程度.

针对一个大型湖泊开展评估, 往往需要对多个样本湖区进行对比调查与评价, 采取客观熵权计算方法 确定指标权重, 根据各指标所含信息有序度的差异性确定权重的方法, 直接根据指标原始数据确定相应指 标权重值,使评价结果能更准确地反映待评湖泊的健康状况.

本研究中, 对公众环境满意度 $\left(\mathrm{C}_{10}\right)$ 这一指标采取客观熵权法来确定权重. 群众对湖荡湿地生态环境的 满意率即湖荡湿地向人类提供服务被人们满意的程度, 是湖荡湿地健康认可方式, 可以从侧面反映湖荡湿 地生态系统的健康状况,通过发放公众对环境满意度的调查问卷进行统计获得.

以上方法获得指标主观权重值 $\alpha=\left[\alpha_{1}, \alpha_{2}, \cdots, \alpha_{n}\right]^{T}$ 和客观权重值 $\beta=\left[\beta_{1}, \beta_{2}, \cdots, \beta_{n}\right]^{T}$, 为融合评价 
指标主客观信息,采用优化方法综合获得指标组合权重 (表 4). 相对于总目标总权重值的计算采用层次总 排序的方法处理.

表 4 核心评价指标与权重

Tab.4 Core assessment index and weight

\begin{tabular}{|c|c|c|c|c|c|}
\hline \multicolumn{2}{|c|}{ A-H 权重 } & \multicolumn{2}{|c|}{ B-A 权重 } & \multicolumn{2}{|l|}{$\mathrm{C}-\mathrm{B}$ 权重 } \\
\hline 湖荡湿地自然生态 & 0.8 & 物理 $\left(B_{1}-A_{1}\right)$ & 0.1 & 口门畅通率 $\left(\mathrm{C}_{1}-\mathrm{B}_{1}\right)$ & 0.2 \\
\hline \multirow[t]{6}{*}{ 健康系统 $\left(A_{1}-\mathrm{H}\right)$} & & & & 湖水交换能力 $\left(\mathrm{C}_{2}-\mathrm{B}_{1}\right)$ & 0.2 \\
\hline & & & & 受损水体修复潜力 $\left(\mathrm{C}_{3}-\mathrm{B}_{1}\right)$ & 0.6 \\
\hline & & 化学 $\left(B_{2}-A_{1}\right)$ & 0.5 & 综合水质指标 $\left(\mathrm{C}_{4}-\mathrm{B}_{2}\right)$ & 0.6 \\
\hline & & & & 富营养指数 $\left(\mathrm{C}_{5}-\mathrm{B}_{2}\right)$ & 0.4 \\
\hline & & 生物 $\left(\mathrm{B}_{3}-\mathrm{A}_{1}\right)$ & 0.4 & 蓝藻密度 $\left(\mathrm{C}_{6}-\mathrm{B}_{3}\right)$ & 0.6 \\
\hline & & & & 生物多样性 $\left(\mathrm{C}_{7}-\mathrm{B}_{3}\right)$ & 0.4 \\
\hline 湖荡湿地社会服务 & 0.2 & 社会服务 $\left(\mathrm{B}_{4}-\mathrm{A}_{2}\right)$ & 1 & 调蓄防洪能力 $\left(\mathrm{C}_{8}-\mathrm{B}_{4}\right)$ & 0.2 \\
\hline \multirow[t]{2}{*}{ 功能系统 $\left(A_{2}-H\right)$} & & & & 水功能区水质达标率 $\left(\mathrm{C}_{9}-\mathrm{B}_{4}\right)$ & 0.3 \\
\hline & & & & 公众环境满意度 $\left(\mathrm{C}_{10}-\mathrm{B}_{4}\right)$ & 0.5 \\
\hline
\end{tabular}

1.3.3 水生态系统健康评价标准 湖荡湿地生态系统健康状况是指标体系状态值的完整反映. 本次评估指 标标准区间的确定依据为:

(1)相关研究成果和数据, 比如国内外关于湖泊评估相似指标的阈值标准; (2)国家和地区相关标准, 如国 家《地表水环境质量标准》(GB 3838-2002) 、《景观娱乐用水水质标准》(GB 12941-1991) 以及国家和研究 地区颁布的相关行业标准; (3)参照点法, 选取历史资料记载的较好条件下的状态作为参照标准, 也可以以研 究区域的背景值和本底值以及相似自然和社会环境下某一湖泊状态作为参照值; (4)流域及相关管理部门对 湖泊的规划与环境保护目标; (5)专家咨询以及公众意愿确定的目标. 权衡多种标准并充分考虑待评湖泊实 际特征的基础上确定最终标准, 其中创造性的提出将湖荡湿地受损水体修复潜力这一因素作为评价指标之 一. 指标分级区间考虑分为 I、II、II、IV 级, 对应优、良、中、差 4 个级别, 确定了太湖流域湖荡湿地评价指标 标准区间 (表 5).

因此,为形象表述太湖流域湖荡湿地评价结果, 本研究采用百分制对太湖流域湖荡湿地指数所属标准 进行限值: 对应 $0 \sim 100$ 数值区间把太湖流域湖荡湿地状态分为 I 、II III 、IV 级, 对应优、良、中、差 4 个级别 (表 6).

\section{2 结果分析与讨论}

\section{1 太湖流域湖荡湿地修复潜力分析}

滆湖、澄湖、昆承湖、宜兴三氿、淀山湖受损水体修复潜力较差, 长荡湖受损潜力中等水平, 阳澄湖、尚 湖、元荡受损水体修复潜力良好,钱资湖修复能力较好.

阳澄湖、长荡湖等湖荡沉水植被覆盖度在 $15 \%$ 25\% 左右, 但发育并不好, 种类较少. 尚湖、钱资荡水质 较好, 水生植物发育良好, 生态系统健康状态较好, 恢复潜力较大. 滆湖沉水植物覆盖度较低, 且植物种类较 少,修复潜力较低.

典型封闭性水源地尚湖、钱资荡水质较好, 水生植物发育良好, 生态系统健康状态较滆湖、阳澄湖好, 但 仍有待提高, 恢复潜力较大. 尚湖沉水植被覆盖度相对较高, 约为 $30 \%$, 以穗花狐尾藻、蕰草等耐污种为主. 阳澄湖、长荡湖等湖荡沉水植被覆盖度在 $15 \%$ 25\%左右, 但发育并不好, 种类较少, 浮叶植物以荇菜、菱角 等占优势, 水生植被分布情况如图 2. 近十多年来, 排人滆湖的工业废水和生活污水在不断增加, 致使湖体水 质污染和富营养化程度日益加重. 自 1990s 以来, 滆湖水草呈急剧衰退的态势. 2009 年 10 月, 滆湖南部湖区 有苦草呈点状分布, 覆盖度占南部湖区的 $5 \%$, 中部湖区仅有马来眼子菜呈点状分布, 北部大洪港围垦区仍 有块状分布的金鱼藻, 伴生薄草、黑藻、苦草和马来眼子菜, 覆盖度占大洪港的 $90 \%$, 总覆盖度不足全湖面积 的 $1 \% .2010$ 年全湖沉水植物覆盖度仅为全湖面积的 $0.78 \%$, 种类包括金鱼藻、狐尾藻、水遁草、苦草和菹草 


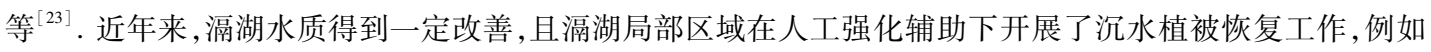
大洪港地区存在部分沉水植被,然而滆湖环境条件仍不具备全湖范围内沉水植被生态恢复 (表 7).

表 5 评价指标分级标准

Tab.5 Preliminary grading standards of assessment index

\begin{tabular}{|c|c|c|c|c|c|c|c|c|c|}
\hline \multirow{2}{*}{$\begin{array}{c}\text { 目标 } \\
\text { 层 }(\mathrm{H})\end{array}$} & \multirow{2}{*}{$\begin{array}{l}\text { 类别 } \\
\text { 层 }(A)\end{array}$} & \multirow{2}{*}{$\begin{array}{l}\text { 要素 } \\
\text { 层(B) }\end{array}$} & \multirow{2}{*}{\multicolumn{2}{|c|}{ 指标 }} & \multicolumn{5}{|c|}{ 分级标准 } \\
\hline & & & & & \multicolumn{2}{|c|}{ 优 } & 良 & 中 & 差 \\
\hline 太湖 & 湖荡湿 & 物理 & \multicolumn{2}{|c|}{ 门口畅通率/\% } & \multicolumn{2}{|c|}{$[80,100]$} & {$[70,80)$} & {$[50,70)$} & {$[0,50)$} \\
\hline 流域 & 地自然 & (B1) & \multicolumn{2}{|c|}{ 湖水交换能力 } & \multicolumn{2}{|c|}{$[1.5,2)$} & {$[1,1.5)$} & {$[0.5,1)$} & {$[0,0.5)$} \\
\hline $\begin{array}{l}\text { 湖荡 } \\
\text { 湿地 }\end{array}$ & $\begin{array}{l}\text { 生态健 } \\
\text { 康系统 }\end{array}$ & & \multicolumn{2}{|c|}{$\begin{array}{c}\text { 受损水体修复潜力 } \\
\text { (水深/透明度) }\end{array}$} & \multicolumn{2}{|c|}{$[1,2)$} & $(2,2.5]$ & $(2.5,3]$ & $(3,5]$ \\
\hline \multirow{13}{*}{$\begin{array}{l}\text { 综合 } \\
\text { 指数 } \\
(\mathrm{H})\end{array}$} & $(\mathrm{A} 1)$ & 化学 & 综合水 & & I & II & III & IV & V \\
\hline & & (B2) & 质指标 & $\mathrm{DO} /(\mathrm{mg} / \mathrm{L})$ & {$[7.5,10)$} & $(6,7.5]$ & $(5,6]$ & $(3,5]$ & $(2,3]$ \\
\hline & & & ( GB 3838- & $\mathrm{NH}_{4}^{+}-\mathrm{N} /(\mathrm{mg} / \mathrm{L})$ & $(0,0.15]$ & $(0.15,0.5]$ & $(0.5,1.0]$ & $(1.0,1.5]$ & $(1.5,2.0]$ \\
\hline & & & 2002) & $\mathrm{TN} /(\mathrm{mg} / \mathrm{L})$ & $(0,0.2]$ & $(0.2,0.5]$ & $(0.5,1.0]$ & $(1.0,1.5]$ & $(1.5,2.0]$ \\
\hline & & & & $\mathrm{TP} /(\mathrm{mg} / \mathrm{L})$ & $(0,0.01]$ & $(0.01,0.025]$ & $(0.025,0.05]$ & $(0.05,0.1]$ & $(0.1,0.2]$ \\
\hline & & & CDOM 吸收 & 系数 $a(350) / \mathrm{m}^{-1}$ & \multicolumn{2}{|c|}{$[1,2)$} & {$[2,3)$} & {$[3,4)$} & {$[4,5)$} \\
\hline & & & \multirow{2}{*}{\multicolumn{2}{|c|}{ 富营养化指数 }} & \multirow{2}{*}{\multicolumn{2}{|c|}{$\begin{array}{l}\text { 贫营养 } \\
{[0,20]}\end{array}$}} & 中营养 & 轻度富营养 & 中、重度富营养 \\
\hline & & & & & & & $(20,50]$ & $(50,60]$ & $(60,100]$ \\
\hline & & 生物 & \multicolumn{2}{|c|}{ 蓝藻密度/(×104 cells/L) } & \multicolumn{2}{|c|}{$[0,300]$} & $(300,1700]$ & $(1700,3500]$ & $>3500$ \\
\hline & & (B3) & \multicolumn{2}{|c|}{ 水生生物多样性 } & \multicolumn{2}{|c|}{$\geqslant 3$} & $(3,2]$ & $(2,1]$ & $(1,0]$ \\
\hline & 湖荡湿地社 & ：社会 & \multicolumn{2}{|c|}{ 调蓄防洪能力/\% } & \multicolumn{2}{|c|}{$[80,100]$} & {$[70,80)$} & {$[50,70)$} & {$[0,50)$} \\
\hline & \multirow{2}{*}{$\begin{array}{l}\text { 会服务功能 } \\
\text { 系统 }(A 2)\end{array}$} & 服务 & 水功能区 & 水质达标率/\% & \multicolumn{2}{|c|}{$[80,100]$} & {$[70,80)$} & {$[50,70)$} & {$[0,50)$} \\
\hline & & (B4) & \multicolumn{2}{|c|}{ 公众环境满意度/\% } & \multicolumn{2}{|c|}{$[80,100]$} & {$[70,80)$} & {$[50,70)$} & {$[0,50)$} \\
\hline
\end{tabular}

表 6 太湖流域湖荡湿地评价分级标准

Tab.6 Assessment criterion of lake wetlands in Taihu Basin

\begin{tabular}{ccc}
\hline $\begin{array}{c}\text { 生态系 } \\
\text { 统分级 }\end{array}$ & $\begin{array}{c}\text { 生态系统 } \\
\text { 综合指数 }\end{array}$ & $\begin{array}{c}\text { 生态系统 } \\
\text { 健康状态 }\end{array}$ \\
\hline I & $80 \sim 100$ & 优 \\
II & $60 \sim 80$ & 良 \\
III & $40 \sim 60$ & 中 \\
IV & $0 \sim 40$ & 差 \\
\hline
\end{tabular}

湖泊生态健康评价结果与湖泊的水质、富营养化、水生 生物现状分析结果吻合. 受人类活动干扰较为严重的湖泊以 及具有养殖功能的湖荡生态系统较差, 淀山湖和澄湖属于过 水性湖荡, 换水周期 20 余天, 湖荡上游经济开发活动所引起 的人湖污染负荷对湖内水质影响比对其他湖荡影响更大, 长 期处于中度或重度富营养化状态. 长荡湖、滆湖、阳澄湖、澄 湖、元荡等目前主要功能用途仍为养殖, 养殖投饵带人湖体 内的氮、磷等营养物质也逐年增多, 湖荡生态系统较为脆弱. 而由于当地政府对长荡湖实施了综合整治工程, 水质有所改 善,生态系统健康状态为良.

表 7 太湖流域典型湖荡湿地单项指标 (受损水体修复潜力) 评价结果

Tab.7 Assessment results of water restoration potential of the typical lake wetlands in Taihu Basin

\begin{tabular}{|c|c|c|c|c|c|c|c|c|c|c|}
\hline & 滆湖 & 阳澄湖 & 长荡湖 & 澄湖 & 尚湖 & 钱资荡 & 昆承湖 & 宜兴三氿 & 元荡 & 淀山湖 \\
\hline 综合评价指数 & 14 & 71 & 50 & 28 & 78 & 87 & 40 & 8 & 78 & 17 \\
\hline $\begin{array}{l}\text { 受损水体修复潜力 } \\
\text { 评估结果 }\left(\mathrm{C}_{3}\right)\end{array}$ & 差 & 良 & 中 & 差 & 良 & 优 & 差 & 差 & 良 & 差 \\
\hline
\end{tabular}

\section{2 太湖流域湖荡湿地生态健康总体状况}

太湖流域典型湖荡湿地生态系统健康评价的结果如表 8 所示, 尚湖和钱资荡生态系统健康等级为优, 长荡湖生态系统健康等级为良, 阳澄湖、昆承湖、元荡和淀山湖生态系统处于中等健康状态, 滆湖、澄湖以及 宜兴三氿生态健康较差. 


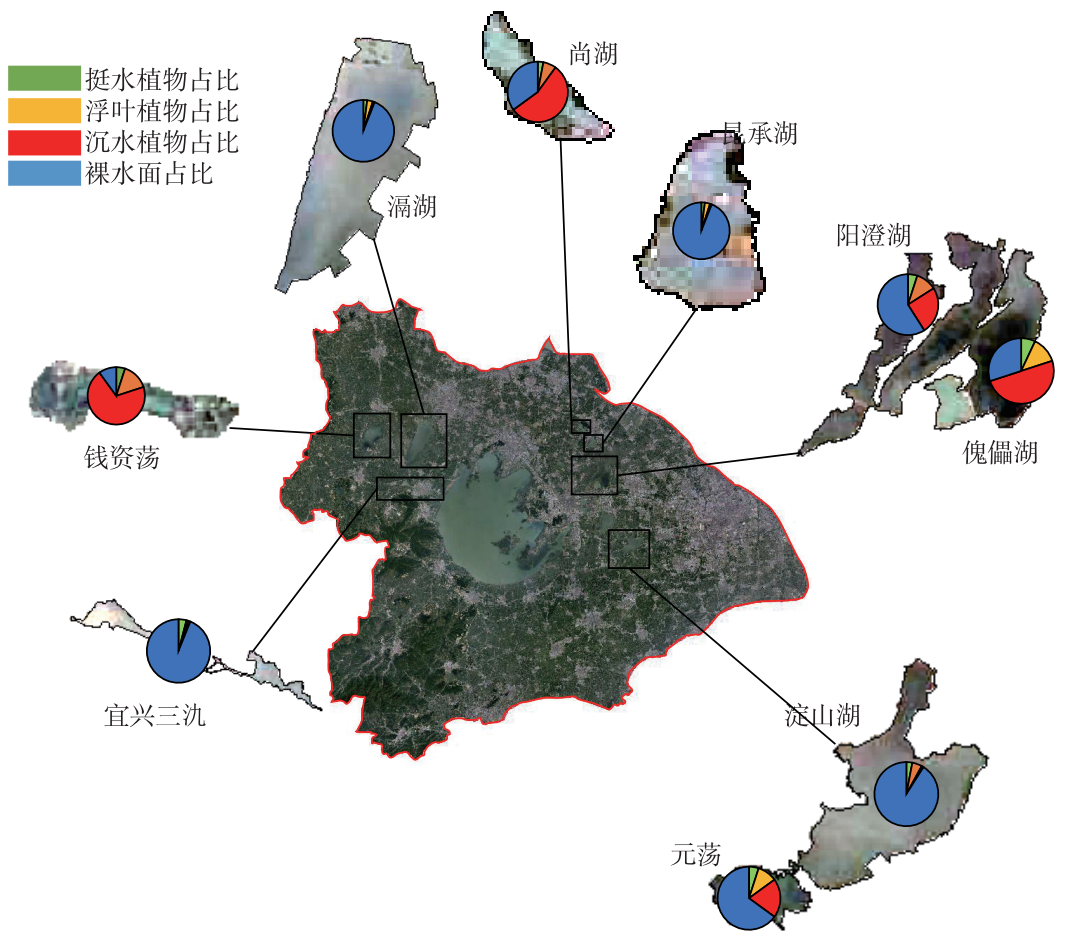

图 2 太湖流域水生植被分布

Fig.2 Distribution of aquatic vegetation in Taihu Basin

表 8 太湖流域典型湖荡湿地生态系统健康综合评价结果及单项指标(综合水质指标)评价结果

Tab.8 Comprehensive assessment results of ecosystem health of the typical lake wetlands and assessment results of comprehensive water quality index of the typical lake wetlands in Taihu Basin

\begin{tabular}{cccccc}
\hline 湖泊名称 & 面积 $/ \mathrm{km}^{2}$ & 平均水深 $/ \mathrm{m}$ & 综合得分 & 生态系统健康等级 & 水质污染指数评估结果 $\left(\mathrm{C}_{4}\right)$ \\
\hline 滆湖 & 164 & 1.20 & 39 & 差 & 差 \\
阳澄湖 & 119.04 & 1.82 & 59 & 中 & 中 \\
长荡湖 & 89 & 1.10 & 64 & 良 & 差 \\
澄湖 & 45 & 1.83 & 35 & 差 & 良 \\
尚湖 & 8 & 1.9 & 83 & 优 & 中 \\
钱资荡 & 6.9 & 1.0 & 80 & 中 & 差 \\
昆承湖 & 18 & 1.78 & 50 & 中 & 差 \\
宜兴三氿 & 13.5 & 1.4 & 34 & 中 & 中 \\
元荡 & 12.9 & 2.6 & 65 & 48 & 羑 \\
淀山湖 & 62 & 2.1 & &
\end{tabular}

太湖流域湖荡湿地的这 11 个小湖荡的生态健康综合评价结果与湖泊的水质综合评价分析结果吻合 (图 3).

\section{3 太湖流域湖荡湿地生态健康状况影响因素分析}

1) 人湖污染物对太湖流域湖荡湿地生态系统健康的影响. 近年来, 太湖流域水污染事故频发, 部分湖泊 在短短的 20 年内从过去的中营养 $\rightarrow$ 轻度富营养 $\rightarrow$ 轻度中富营养到现在的重度富营养, 严重影响了沉水植 


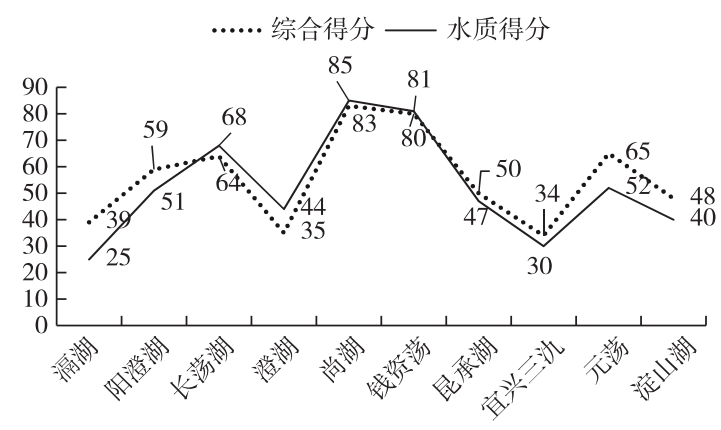

图 3 太湖流域湖荡湿地综合评价 结果与水质综合评价结果

Fig.3 Comprehensive assessment results of ecosystem health and assessment results of comprehensive water quality index of the typical lake wetlands in Taihu Basin
物的生长. 近年来大量研究指出太湖流域湖荡湿 地人湖污染负荷逐年加重, 结果表明人湖污染负 荷的加重是造成近年来太湖流域湖荡湿地净化 能力退化的重要原因, 也是影响太湖流域湖荡湿 地水生态系统健康的最重要因素.

以长荡湖为例, 长荡湖水源主要来自环湖河 港人流和湖面降水补给, 主要污染源为进出湖河 流携带的污染和围网养殖污染, 导致湖泊富营 养化 ${ }^{[24]}$.

统计分析显示 4 项指标的单位水量人湖污 染负荷与太湖沿岸平均质量浓度具有显著的正 相关关系 (表 9), $\mathrm{NH}_{4}^{+}-\mathrm{N}$ 浓度与 $\mathrm{TP}$ 浓度有明显 的正相关关系. 说明外源污染是湖泊污染来源的 重要途径, 环太湖主要人湖河流带人的污染负荷 是影响太湖沿岸水质的主要原因之一. 人湖河道

$\mathrm{TN} 、 \mathrm{TP} 、 \mathrm{COD}_{\mathrm{Mn}}$ 的严重超标是造成太湖 N、P 以及有机污染的主要原因.

2) 围网养殖对太湖流域湖荡湿地生态系统健康的影响. 围网养殖加速了太湖流域湖荡湿地的富营养化 进程. 大规模的围网养殖也占据了沉水植被的生长空间. 高月香等对太湖流域江苏地区代表性水产养殖排 污系数进行了测算研究 (表 10), 发现围网养殖对太湖流域湖荡湿地生态系统健康具有一定的影响, 并且排 污系数因养殖品种不同存在较大差异 ${ }^{[25]}$.

表 9 各指标单位水量人湖污染负荷与太湖沿岸平均浓度的相关系数

Tab.9 The correlation coefficient between the pollutant load of per unit water quantity of the rivers and average pollutant density around Lake Taihu

\begin{tabular}{|c|c|c|c|c|}
\hline \multirow{2}{*}{ 环湖河道 } & \multicolumn{4}{|c|}{ Pearson 相关性系数 } \\
\hline & $\mathrm{COD}_{\mathrm{Mn}}$ 污染负荷 & $\mathrm{NH}_{4}^{+}-\mathrm{N}$ 污染负荷 & TP 污染负荷 & $\mathrm{TN}$ 污染负荷 \\
\hline$\rho\left(\mathrm{COD}_{\mathrm{Mn}}\right)$ & $0.956^{* *}$ & $0.827^{*}$ & 0.223 & $0.907^{* *}$ \\
\hline$\rho\left(\mathrm{NH}_{4}^{+}-\mathrm{N}\right)$ & 0.600 & $0.938^{* * *}$ & 0.291 & $0.920^{* *}$ \\
\hline$\rho(\mathrm{TP})$ & 0.071 & 0.352 & $0.918^{* * *}$ & 0.423 \\
\hline$\rho(\mathrm{TN})$ & 0.561 & $0.861^{\text {** }}$ & 0.356 & $0.895^{*}$ \\
\hline
\end{tabular}

表 10 围网养殖模式下太湖流域不同养殖品种的排污系数 (均值 \pm 标准差, $\mathrm{kg} / \mathrm{t}$ )

Tab.10 Pollutant discharge coefficient of aquaculture in Taihu Basin $(\mathrm{kg} / \mathrm{t})$

\begin{tabular}{cccrrr}
\hline 养殖模式 & 养殖品种 & $\mathrm{TN} /(\mathrm{kg} / \mathrm{t})$ & $\mathrm{TP} /(\mathrm{kg} / \mathrm{t})$ & 铜 $/(\mathrm{kg} / \mathrm{t})$ & 锌 $/(\mathrm{kg} / \mathrm{t})$ \\
\hline \multirow{2}{*}{ 围网 } & 鲢鳙 & $-13.51 \pm 1.27$ & $-2.870 \pm 0.410$ & $-0.0008 \pm 0.0001$ & $-0.0058 \pm 0.0007$ \\
& 中华线鳌蟹(东太湖) & $90.03 \pm 13.94$ & $41.395 \pm 5.763$ & $0.0365 \pm 0.0100$ & $0.2198 \pm 0.0571$ \\
& 中华线鳌蟹(滆湖) & $16.80 \pm 3.10$ & $2.800 \pm 0.099$ & $0.0020 \pm 0.0002$ & $0.0261 \pm 0.0108$ \\
\hline
\end{tabular}

3 ) 蓝藻水华对太湖流域湖荡湿地水生态系统健康的影响. 蓝藻的大量生长改变了太湖流域湖荡湿地水 体的理化环境, 使透明度降低, DO 减少. 而且蓝藻大量死亡, 释放大量有害气体及蓝藻毒素导致水生态系统 迅速崩溃.

范亚民等于 2014 年 8 月期间对贡湖湾某水厂水源水及出厂水中浮游植物胞内及胞外微囊藻毒素 (MCs) 浓度进行了调查检测, 数据分析发现, 水源水中胞内与胞外 MCs 浓度之间呈显著正相关, 胞内 MCs 浓 度与 $\mathrm{TN}$ 浓度、 $\mathrm{NH}_{4}^{+}-\mathrm{N}$ 浓度、 $\mathrm{TP}$ 浓度、 $\mathrm{COD}_{\mathrm{Mn}}$ 和浊度呈显著相关, 而胞外 $\mathrm{MCs}$ 浓度与 $\mathrm{TN}$ 浓度、 $\mathrm{TP}$ 浓度、 $\mathrm{COD}_{\mathrm{Mn}}$ 、浊度和叶绿素 a 浓度呈显著正相关; 逐步回归结果显示, TP 对胞内 MCs 浓度变化的解释率最高, 而 
胞外 MCs 浓度变化主要与胞内 MCs 浓度相关. 最终, 通过对出厂饮用水中 MCs 浓度非致癌风险指数的计算 发现,出厂饮用水对人类健康的威胁较小,但致癌风险相对较高 ${ }^{[26]}$.

4) 水生植物分布对太湖流域湖荡湿地生态系统健康的影响. 生物多样性是维持湖泊生态系统健康稳定 的必要条件. 目前太湖流域部分湖荡湿地,如滆湖,受到不同程度的污染,造成水生植被消亡,水体自净能力 退化甚至丧失, 也严重影响了太湖流域湖荡湿地的水生态系统健康状况, 从而导致湖荡湿地水生植物生物 多样性下降和和水体自净能力减弱.

\section{3 结论}

1) 本评价方法提出将受损水体修复潜力作为评价太湖流域湖荡湿地生态系统健康等级的一个重要指 标. 针对太湖流域湖荡湿地受损水体修复潜力的评价结果也与现状符合: 滆湖、澄湖、昆承湖、宜兴三沈、淀 山湖受损水体修复潜力较差, 长荡湖受损水体修复潜力中等水平, 阳澄湖、尚湖、元荡受损水体修复潜力良 好, 钱资湖修复能力较好.

2) 对研究区域湖荡湿地生态环境现状分析发现, 在整个太湖流域湖荡湿地中生态系统健康等级为优的 湖荡湿地占 $27.27 \%$, 如典型封闭性水源地傀儡湖、尚湖和钱资荡, 水生植物发育良好, 属于中营养湖泊; 生态 系统健康等级为良的湖荡湿地占 $9.09 \%$, 如水生植被以浮叶植物为主的长荡湖, 属于中度富营养状态; 中等 生态系统健康水平的湖荡湿地居多, 占 $36.36 \%$, 如阳澄湖、昆承湖、元荡和淀山湖, 属于轻一中度富营养状 态; 生态系统健康等级为差的湖荡湿地占 $18.18 \%$, 如滆湖、澄湖以及宜兴三氿, 其中, 澄湖和滆湖处于富营养 化程度较重的湖泊.

3) 太湖流域湖荡湿地生态健康的主要影响因素有人湖污染负荷、围网养殖、蓝藻水华、水生植被分布这 4 个主要因素. 如人湖污染负荷这一因素对长荡湖的生态健康影响较大, 滆湖及东太湖流域受围网养殖及水 生植被分布影响较大,蓝藻水华这一因素易产生有毒物质进而影响太湖流域生物健康.

\section{4 参考文献}

[ 1 ] Hughes F. Wetland ecology: Principles and conservation: 2nd edition. Freshwater Biology, 2014, 56(11): 683-685.

[ 2 ] Arias ME, Cochrane TA, Kummu M et al. Impacts of hydropower and climate change on drives of ecological productivity of southeast asia's most important wetland. Ecological Modeling, 2014, 272 : 252-263.

[ 3 ] Bunn SE, Abal EG, Smith MJ et al. Integration of science and monitoring of river ecosystem health to guide investments in catchment protection and rehabilitation. Freshwater Biology, 2010, 55(1) : 223-240.

[ 4 ] Costanza R ed. Ecological economic issues and considerations in indicator development, selection, and use: Toward an operational definition of system health. Barking: Elsevier Science Publishers Ltd, 1992.

[ 5 ] Costanza R, Norton BG, Haskell BD. Ecosystem health: New goals for environmental management. Ecosystem Health New Goals for Environmental Management, 1992.

[ 6 ] Cui BS, Yang ZF. Research review on wetland ecosystem health. Chinese Journal of Ecology, 2001, 20(3) : 31-36. [ 崔保 山, 杨志峰. 湿地生态系统健康研究进展. 生态学杂志, 2001, 20(3) : 31-36.]

[ 7 ] Erwin KL. Wetlands and global climate change: The role of wetland restoration in a changing world. Wetlands Ecology and Management, 2009, 17(1): 71-84.

[ 8 ] Jorgensen SE. Energy and ecological buffer capacities as measures of ecosystem health. Ecosystem Health, 1995, 1(3): 150-160.

[ 9 ] Karr JR. Assessing biological integrity in running waters: A method and its rationale. Illinois Natural History Survey Special Publication, 1-28 No.5, 1986, 5.

[10] Mageau MT, Costanza R, Ulanowicz RE. The development and initial testing a quantitative assessment of ecosystem health. Acta Psychiatrica Scandinavica, 1995, 1(2) : 201-213.

[11] Xu F. Ecosystem health assessment of Lake Chao, a shallow eutrophic Chinese lake. Lakes \& Reservoirs Research \& Management, 1996, 2(1/2): 101-109.

[12] Mai SZ, Xu SJ, Pan, YJ. Application of the PSR model to the evaluation of wetland ecosystem health. Tropical Geography, 2005, 25(4) : 317-321. [麦少芝, 徐颂军, 潘颖君. PSR 模型在湿地生态系统健康评价中的应用. 热带地理, 2005, 
25(4) : 317-321.]

[13] Liu J, Jia'erheng - Ahati, Qiu XY et al. Water ecosystem health evaluation for Bositeng Lake. Heilongjiang Science and Technology of Water Conservancy, 2013, 41(4): 125-127. [刘江, 贾尔恒·阿哈提, 邱秀云等. 湖泊生态健康评价. 黑 龙江水利科技, 2013, 41(4): 125-127.]

[14] Hou SY, Liu DW, Guo LF. Water ecology evaluation and restoration measures in marine river basin. The eighth national river and lake governance and water ecological civilization development BBS papers in 2016, 2016: 150-157. [侯思琰, 刘德文, 郭丽峰. 海河流域水生态评价及修复措施. 2016 第八届全国河湖治理与水生态文明发展论坛论文集, 2016: 150-157.]

[15] Hu ZX, Hu WP, Gu XH et al. Assessment of Ecosystem Health in Lake Taihu. J Lake Sci, 2005, 17(3) : 256-262. DOI: 10.18307/2005.0311. [ 胡志新, 胡维平, 谷孝鸿等. 太湖湖泊生态系统健康评价. 湖泊科学, 2005, 17 (3): 256-262.]

[16] Cai K, Qin CY, Li JY et al. Preliminary study on phytoplanktonic index of biotic integrity ( P-IBI) assessment for lake ecosystem health: a case of Taihu Lake in Winter, 2012. Acta Ecologica Scinica, 2016, 36( 5) : 1431-1441. [蔡琨, 秦春 燕, 李继影等. 基于浮游植物生物完整性指数的湖泊生态系统评价一以 2012 年冬季太湖为例. 生态学报, 2016, 36(5) : 1431-1441.]

[17] Xu Y, Gao JF, Gao YN et al. Spatial variation and dynamics of ecosystem health in the Taihu Lake Watershed. Resources Science, 2011, 33(2) : 201-209. [许妍, 高俊峰, 高永年等. 太湖流域生态系统健康的空间分异及其动态转移. 资 源科学, $2011,33(2):$ 201-209.]

[18] Chen Q, Xu DJ, Zhang X et al. A Preliminary Benthic Index of Biotic Integrity ( B-IBI) for bioassessment of the plain waterway network of Taihu Basin. Research of Environment Science, 2013, 26(12) : 1301-1308. [ 陈桥, 徐东昫, 张翔等. 太湖流域平原水网区底栖动物完整性健康评价. 环境科学研究, 2013, 26(12): 1301-1308.]

[19] Ge F, Ye C, Feng GY et al. A research for water ecosystem entropy comprehensive health index method in the lakefront of Taihu Lake. Journal of Inner Mongolia Normal University: Natural Science Edition, 2010, 39(6): 623-626. [戈锋, 叶 春, 冯冠宇等. 基于熵权综合健康指数法的太湖湖滨带水生态系统研究. 内蒙古师范大学学报: 自然科学汉文版, $2010,39(6): 623-626$.

[20] Zhang SS, Zhang L, Zhang LC et al. Coupling relationship between polluting industrial agglomeration and water environment pollution in southern Jiangsu of Taihu Lake Basin. Scientia Geographica Sinica, 2018, 38(6) : 954-962.] [张姗 姗, 张砧, 张落成等. 苏南太湖流域污染企业集聚与水环境污染空间耦合关系. 地理科学, 2018, 38 (6): 954-962.]

[21] Jin XC, Tu QY eds. Criteria for investigation of lake eutrophication: the second edition. Beijing: China Environmental Science Press, 1990: 239-252. [ 金相灿, 屠清瑛. 湖泊富营养化调查规范: 第二版. 北京: 中国环境科学出版社, 1990: 239-252.]

[22] Qin BQ, Zhang YL, Gao G et al. Key factors affecting lake ecological restoration. Progress in Geography, 2014, 33(7) : 918-924. [秦伯强, 张运林, 高光等. 湖泊生态恢复的关键因子分析. 地理科学进展, 2014, 33(7) : 918-924.]

[23] Tao H, Pan JZ, Shen YL et al. Overview and degradation reasons of submerged macrophytes of Gehu Lake. Environmental Science and Technology, 2010, 23(5) : 64-68. [ 陶花, 潘继征, 沈耀良等. 滆湖沉水植物概况及退化原因分析. 环境 科技, 2010, 23(5): 64-68.]

[24] Jin BB, Zhu L, Li YP et al. Assessment of water quality improvement effect of Changdang Lake by reduction of pollution load into the lake. Sichuan Environment, 2015, 34(4): 50-56. [靳斌斌, 朱亮, 李一平等. 人湖污染负荷消减对长荡 湖水质改善效应评估. 四川环境, 2015, 34(4): 50-56.]

[25] Gao YX, Zhang YM, Wang WM et al. Study on calculation of representative aquaculture pollution discharging coefficients in the Taihu Lake basin within Jiangsu Province. Journal of Agro-Environment Science, 2017, 36(7): 1330-1336. [高月 香, 张毅敏, 王伟民. 太湖流域江苏地区代表性水产养殖排污系数测算研究. 农业环境科学学报, 2017, 36(7): 1330-1336. ]

[26] Fan YM, Jiang WL, Liu BG et al. Temporal microcystin dynamics of the source water and finished water in a waterworks of Lake Taihu. J Lake Sci, 2018, 30(1) : 25-33. DOI : 10.18307/2018.0103. [范亚民, 姜伟立, 刘宝贵等. 蓝藻水华暴 发期间太湖贡湖湾某水厂水源水及出厂水中微囊藻毒素污染分析及健康风险评价. 湖泊科学, 2018, 30 (1): 25-33. ] 